УДК 343.85

DOI https: / / doi.org/10.32837 / yuv.v0i6.2050

I. Довбань,

кандидат юридичних наук

\title{
СПЕЦІАЛЬНО-КРИМІНОЛОГІЧНІ ЗАХОДИ ЗАПОБІГАННЯ ЗЛОЧИНАМ, ЩО ВЧИНЯЮТЬСЯ ДЕРЖАВНИМИ СЛУЖБОВЦЯМИ
}

Постановка проблеми. Злочинність і боротьба з нею в Україні є надзвичайно складними й актуальними проблемами. Нестабільність суспільно-політичної та економічної ситуації, недосконалість механізму державного управління, відсутність реального дієвого громадського контролю за діяльністю органів державної влади, зниження життєвого рівня населення, корупція у всіх без винятку гілках влади, зокрема у правоохоронних органах, створили умови для розвитку й утвердження злочинності в суспільному житті держави. Стрімке зростання (за багатьма показниками) і збільшення масштабів цього явища, поширення впливу на всі соціальні сфери становлять реальну загрозу національній безпеці, ставлять перед суб'єктами протидії злочинності нові завдання та змушують відшуковувати дієві заходи запобігання ним.

Аналіз останніх досліджень i публікацій. Теоретико-методологічну основу написання статті становлять наукові праці вітчизняних і зарубіжних учених, зокрема B.C. Батиргареєвої, І.Г. Богатирьова, О.Ю. Бусол, В.В. Голіни, Б.М. Головкіна, А.Л. Гуринської, I.M. Даньшина, С.Ф. Денисова, Т.А. Денисової, О.М. Джужі, А.І. Долгової, В.М. Дрьоміна, А.П. Закалюка, А.Ф. Зелінського, О.Г. Кальмана, I.I. Карпеця, I.M. Клеймьонова, О.Г. Колба, І.М. Копотуна, O.M. Костенка, В.М. Кудрявцева, O.M. Литвака, О.М. Литвинова, В.В. Лунєєва, В.К. Максимова,
O.А. Мартиненка, M.I. Мельника, В.А. Мисливого, П.П. Михайленка, А.А. Музики, О.В. Старкова, В.О. Тулякова, В.І. Шакуна.

Водночас низка теоретичних i практичних питань, пов'язаних з удосконаленням заходів запобігання злочинам, що вчиняються державними службовцями, є нерозв'язаною.

Постановка завдання. Метою статті $€$ визначення спеціально-кримінологічних заходів запобігання злочинам, що вчиняються державними службовцями.

Виклад основного матеріалу дослідження. Відповідно до ст. 19 КонституціїУкраїни, органи державної влади та місцевого самоврядування, ïх посадові особи зобов'язані діяти лише на підставі, у межах повноважень та у спосіб, що передбачені Конституцією та законами України [1]. Ці конституційні приписи поширюються на всіх без винятку службових осіб незалежно від того, чи $€$ вони представниками законодавчої, виконавчої або судової гілки влади, виконують свої службові функції в державному апараті, органах місцевого самоврядування чи в громадських об'єднаннях, здійснюють службову діяльність в юридичних особах публічного чи приватного права [2, с. 5].

Запобігання злочинам як головне завдання боротьби зі злочинністю, закріплене ч. 1 ст. 1 KK України [3], вважається правовим підгрунтям профілактичної діяльності. Елементами запобігання злочинам є профілактика, попередження та припинення. Кожен 
із них є відносно самостійним, окремим сегментом цієї діяльності, але всі вони взаємопов'язані й мають єдину мету, а саме недопущення вчинення злочину [4].

Отже, торкаючись теоретичного аспекту визначення спеціально-кримінологічного запобігання як особливого феномена діяльності щодо протидіï злочинності, нагадуємо про наявні у кримінологічній літературі позиції та погляди вчених на цю проблему. Зокрема, точка зору O.M. Литвака полягає в тому, що останній розмежовує, і з цим слід погодитися, загальносоціальне запобігання (яке збігається iз соціальним прогресом) зі спеціально-кримінологічним запобіганням та репресивну діяльність держави, а також визначає якісні відмінності попереджувальної діяльності, яка орієнтована на досягнення запобіжної мети без застосування примусу. Поіменований учений визначає спеціалізованих суб'єктів (до яких належать лише органи виконавчої влади, для яких запобігання злочинності $€$ однією з основних статутних функцій) та неспеціалізованих (для яких здійснення профілактичного впливу $€$ неосновною функцією в межах своєї конкретної професійної діяльності) [5, c. 22-23].

На думку О.М. Джужі, у широкому сенсі спеціально-кримінологічне запобігання злочинам полягає у цілеспрямованому здійсненні цього виду запобіжної діяльності як функції; зв'язку з елементами системи «по горизонталі» (взаємодія) і «по вертикалі» (підпорядкування); неухильному виконанні команд управляючого механізму системи; виборі лінії поведінки відповідно до стану об'єкта профілактичного впливу [6, с. 63].

Водночас В.В. Голіна у більш вузькому розумінні спеціально-кримінологічне запобігання злочинам розуміє як синтезовану кримінологічну теорію і практику організації протидіï злочинності шляхом розроблення та використання спеціальних знань і методів кримінології та інших галузей (соціології, економіки, психології, педагогіки, антропології, статистики тощо) $[7$, с. 21].

На відміну від інших напрямів запобіжної діяльності, як обгрунтовано довів А.П. Закалюк, заходи спеціально-кримінологічного спрямування чинять вплив не тільки після вчинення злочину, але й частіше до нього; у сфері, яка лише частково регулюється правом; засобами, що мають виключно цільове запобіжне призначення; інколи паралельно із засобами інших різновидів (напрямів) запобігання злочинам (загальносоціального, індивідуального), але частіше після них [8, с. 328-329].

Спеціальне запобігання злочинам, на відміну від загального, як слушно зауважила А.І. Долгова, має цілеспрямований на недопущення злочинів характер. При цьому спеціальна спрямованість на виявлення та усунення (блокування, нейтралізацію) причин, умов, інших детермінант злочинів це іiі профілююча, констатуюча ознака та головна особливість [9, с. 347].

Якщо узагальнити всі визначені в національній та зарубіжній науковій літературі поняття, то слід констатувати, що спеціально-кримінологічний рівень запобігання злочинам - це вже професійна діяльність, яка потребує використання спеціальних знань i методів кримінологіі, спеціальних заходів планування, прогнозування та управління [10, с. 7].

Одним із провідних спеціальних суб'єктів запобігання злочинам, що вчиняються державними службовцями, є Національне антикорупційне бюро України (НАБУ). Це державний правоохоронний орган, на який покладаються попередження, виявлення, припинення, розслідування та розкриття корупційних правопорушень, віднесених до його підслідності, а також запобігання вчиненню нових. Його компетенцію сформульовано надто широко, а конкретизовано у визначених ст. 1 Закону України 
«Про Національне антикорупційне бюро України» завданнях, серед яких слід назвати протидію кримінальним корупційним правопорушенням, які вчинені вищими посадовими особами, уповноваженими на виконання функцій держави або місцевого самоврядування, а також становлять загрозу національній безпеці. Таким чином, НАБУ є органом досудового розслідування щодо відповідної категорії кримінальних правопорушень з вузькою, чітко визначеною підслідністю [11].

Концепція створення НАБУ грунтується на американо-британській моделі боротьби 3 корупцією, яку у 2004 р. запроваджено в Грузії [12]. Головною ланкою у структурі працівників НАБУ $є$ старші детективи та детективи, які здійснюють оперативно-розшукову діяльність і досудове розслідування в кримінальних провадженнях щодо злочинів, які є їм підслідними, а також в інших справах, витребуваних до НАБУ прокурором, що здійснює нагляд за додержанням законів під час проведення оперативно-розшукової діяльності, досудового розслідування працівниками НАБУ.

Найбільше дискусій викликає кримінально-процесуальний статус детектива НАБУ. Найбільш невизначеною $є$ регламентація його статусу як суб'єкта оперативно-розшукової діяльності [13, с. 145-148].

Нині в законодавстві України відсутнє визначення детектива, не зазначено, які повноваження має ця особа, хто може нею стати, що слід вважати детективною діяльністю, тобто відповідні статусні питання законодавчо не унормовано. Експерти вважають, що у цій ситуації такі законодавчі новели не відповідають загальній концепції порядку досудового розслідування, за яким усі дії з проведення досудового розслідування, зокрема проведення слідчих (розшукових) дій та негласних слідчих (розшукових) дій, покладено на слідчого (ст. 40 Кримінального процесуального кодексу (КПК) України), а оперативні підрозділи (ст. 41 КПК України) позбавлені повноважень виконувати будь-які слідчі (розшукові) діï та негласні слідчі (розшукові) дії без письмового доручення слідчого або прокурора. Таке розмежування функцій між службовими особами, які здійснюють досудове розслідування (слідчими), та особами, які виконують доручення слідчих, зокрема щодо проведення негласних слідчих (розшукових) дій (працівники оперативних підрозділів), існує в усіх правоохоронних органах, які мають у своєму складі як органи досудового розслідування, так і оперативні підрозділи. Така «спеціалізація» співробітників правоохоронних органів викликана істотними відмінностями у цілях, формах, методах і засобах роботи в межах виконання кожної з цих функцій [14].

Відповідно до ч. 3 ст. 19 Закону України «Про Національне антикорупційне бюро України», порядок реєстрації, обліку та розгляду заяв і повідомлень про кримінальні правопорушення визначає Директор НАБУ. Однак такий порядок нині врегульовано ст. $214 \mathrm{KПK}$ України, у якій не йдеться про особливості цього порядку в разі реєстрації, обліку та розгляду заяв і повідомлень про кримінальні правопорушення, віднесені законом до підслідності НАБУ. До того ж Положення про Єдиний реєстр досудових розслідувань (ЄРДР), порядок його формування та ведення затверджуються Генеральною прокуратурою України за погодженням, зокрема, з НАБУ. У нині чинній редакції Положення про ЄРДР порядку його формування та ведення особливих процедур для НАБУ не передбачено [15]. Задля запобігання різноманітним проявам зловживання владою або службовим становищем з боку службових осіб НАБУ ч. 3 ст. 19 Закону України «Про Національне антикорупційне бюро України» слід виключити або треба конкретизувати, у чому саме полягає такий порядок.

Відповідно до п. 1 ч. 1 ст. 17 Закону України «Про Національне антикоруп- 
ційне бюро України», детектив НАБУ для виконання покладених на нього обов'язків має право заводити оперативно-розшукові справи на підставі постанови, затвердженої начальником відповідного підрозділу НАБУ, та здійснювати на підставах і в порядку, установлених законом, гласні та негласні оперативно-розшукові заходи. Водночас Закон України «Про оперативнорозшукову діяльність» закріплює лише обов'язок заведення оперативнорозшукових справ. Так, у ч. 1 ст. 9 цього Закону зазначено, що в кожному випадку наявності підстав для проведення оперативно-розшукової діяльності заводиться оперативно-розшукова справа [16]. На підставі вищезазначеного це право НАБУ слід трансформувати в обов'язок.

Безумовно, заходи запобігання злочинам, що вчиняються державними службовцями, також мають бути ефективними під час їх впровадження у практичну діяльність правоохоронної системи, зокрема щодо формування «відомчої» громадської думки про активне заперечення будьяких корупційних проявів у професійній діяльності. Однак з огляду на підвищену увагу й вимоги суспільства до форм, методів і результативності роботи арсенал заходів запобігання потребує доповнення їх в аспекті удосконалення кадрового забезпечення такими заходами:

1) проведення аналізу діяльності окремих державних органів, підрозділів і служб, службових повноважень державних службовців задля виявлення потенційних можливостей для зловживання;

2) запровадження сучасних психотехнологій для проведення професійно-психологічного добору кадрів 3 урахуванням специфіки служби (високий рівень емоційно-стресових навантажень, наявність чинників ризику, підвищених вимог до «морального обличчя» працівника) задля запобігання прийняттю на службу в органи влади осіб, які пов'я- зані з антигромадськими елементами, кримінальними структурами (з числа осіб, які не пройшли психологічний відбір через непридатність до певних видів службової діяльності, утворювати кадровий резерв);

3) визначення переліку посад працівників управлінських ланок, кандидати на заміщення яких підлягають обов’язковій спеціальній перевірці, умов іï проведення, зокрема щодо тих, хто вже працює на цих посадах, переліку обов'язкових документів для особової (кадрової) справи зазначених категорій працівників та умов іï ведення, порядку періодичної ротації таких осіб та їх однорівневого переміщення;

4) запровадження на постійній основі профілактичної ротації керівного складу через кожні п'ять років;

5) розроблення спеціальних програм навчання та підвищення кваліфікації працівників з питань запобігання корупції у професійній та службовій діяльності;

6) запровадження практики оперативного інформування кадрів щодо усіх виявлених фактів корупції серед ix працівників;

7) оприлюднення через засоби масової інформації та прес-службу матеріалів, що пов'язані 3 корупційними діями працівників, запровадження постійної практики радіота телевізійних виступів (звітів) перед населенням керівників територіальних органів 3 висвітленням як позитивних, так і негативних фактів їх роботи на місцях;

8) вирішення проблеми про підвищення рівня матеріального забезпечення державних службовців із низькими окладами та встановлення доплат до їх заробітної плати залежно від кількості та якості роботи, зокрема запровадження грошової та іншої компенсації за роботу в позаробочий час; наприклад, 3 огляду на досвід Грузіі реальне підвищення грошового забезпечення працівників поліції і доведення його до рівня розвинутих 
країн стало можливим завдяки штатним скороченням та оптимізації фінансових витрат, за роки реформи заробітна плата поліцейських різних категорій зросла від 15 до 40 разів; щомісячне грошове забезпечення дільничного інспектора поліції складає від 400 до 500 дол. США, патрульного поліцейського - від 600 до 1 тис. дол. США, начальника відділу, оперативного офіцера, слідчого - до 2 тис. дол. США; грузинські поліцейські мають різні види страхування і преміювання, які передбачають значні надбавки до грошового утримання залежно від участі в розкритті конкретних злочинів, вислуги років тощо; професія поліцейського стала однією 3 найпрестижніших у країні, а конкурс на заміщення вакантних посад за різними службами складає від 10 до 50 осіб на місце [17, с. 393];

9) використання анонімних «телефонів довіри», за допомогою яких будь-який громадянин може повідомити підрозділам внутрішньої безпеки про неправомірні (на його думку) дії державних службовців.

Дієвим заходом запобігання злочинам, що вчиняються державними службовцями, визнається запровадження комісій з етики та службової дисципліни. Своєчасність попередження, виявлення та реагування на правопорушення, вчинені державними службовцями, значною мірою залежить від умілого використання інформації щодо самих фактів правопорушення та службових осіб, які іх вчиняють. Під час організації збирання та оброблення інформації існує потреба в охопленні інформаціі 3 гласних та негласних джерел. Така інформація систематизується, узагальнюється та зберігається в інформаційно-аналітичних системах. Завдяки цьому полегшується аналіз конкретної ситуації та планування заходів щодо запобігання злочинам, що вчиняються державними службовцями.

Висновки. Таким чином, на спеціально-кримінологічному рівні запро- поновано доповнити наявні сьогодні заходи запобігання злочинам, що вчиняються державними службовцями, такими, як покладення на детективів НАБУ обов'язку заводити оперативно-розшукові справи (на зміну права, визначеного п. 1 ч. 1 ст. 17 Закону України «Про Національне антикорупційне бюро України»), що приведе статусне законодавство у відповідність до оперативно-розшукового (ч. 1 ст. 9 Закону України «Про оперативно-розшукову діяльність»); конкретизація порядку реєстрації, обліку та розгляду заяв і повідомлень про кримінальні правопорушення, віднесені законом до підслідності НАБУ, або про необгрунтовані активи шляхом передбачення особливих процедур для НАБУ в Положенні про ЄРДР, порядок його формування та ведення; проведення аналізу діяльності окремих державних органів, підрозділів і служб, службових повноважень державних службовців задля виявлення потенційних можливостей для зловживання; запровадження сучасних психотехнологій для проведення професійно-психологічного добору кадрів 3 урахуванням специфіки служби (високий рівень емоційно-стресових навантажень, наявність чинників ризику, підвищених вимог до «морального обличчя» працівника) задля запобігання прийняттю на службу в органи влади осіб, які пов'язані з антигромадськими елементами, кримінальними структурами (з числа осіб, які не пройшли психологічний відбір через непридатність до певних видів службової діяльності, утворювати кадровий резерв); визначення переліку посад працівників управлінських ланок, кандидати на заміщення яких підлягають обов'язковій спеціальній перевірці, умов іi проведення, зокрема щодо тих, хто вже працює на цих посадах, переліку обов'язкових документів для особової (кадрової) справи зазначених категорій працівників та умов іï ведення, порядку періодичної ротації 
таких осіб та їх однорівневого переміщення; запровадження на постійній основі профілактичної ротації керівного складу через кожні п'ять років; розроблення спеціальних програм навчання та підвищення кваліфікації працівників з питань запобігання корупції у професійній та службовій діяльності; запровадження практики оперативного інформування кадрів щодо усіх виявлених фактів корупції серед їх працівників; оприлюднення через засоби масової інформації та прес-службу матеріалів, що пов'язані з корупційними діями працівників, запровадження постійної практики радіо- та телевізійних виступів (звітів) перед населенням керівників територіальних органів 3 висвітленням як позитивних, так і негативних фактів їх роботи на місцях; вирішення проблеми про підвищення рівня матеріального забезпечення державних службовців із низькими окладами і встановлення доплат до іх заробітної плати залежно від кількості та якості роботи, зокрема запровадження грошової та іншої компенсації за роботу в позаробочий час; використання анонімних «телефонів довіри», за допомогою яких будь-який громадянин може повідомити підрозділам внутрішньої безпеки про неправомірні (на його думку) дії державних службовців; запровадження комісій з етики та службової дисципліни.

У статті визначено спечіально-кримінологічні заходи запобігання злочинам, що вчиняються державними службовиями. На спеціально-кримінологічному рівні запропоновано доповнити наявні сьогодні заходи запобігання злочинам, що вчиняються державними службовиями, такими, як покладення на детективів Національного антикорупційного бюро України обов'язку заводити оперативно-розшукові справи (на зміну права, визначеного п. 1 ч. 1 cm. 17 Закону України «Про Національне антикорупційне бюро
України»), щзо приведе статусне законодавство у відповідність до оперативно-розшукового (ч. $1 \mathrm{~cm} .9$ Закону України «Про оперативнорозшукову діяльність»); конкретизація порядку реєстраціi, обліку та розгляду заяв і повідомлень про кримінальні правопорушення, віднесені законом до підслідності Наиіонального антикорупиійного бюро України, або про необтрунтовані активи иляхом передбачення особливих процедур для Національного антикорупційного бюро України в Положенні про Єәиний реєстр досудових розслідувань, порядок його формування та ведення; проведення аналізу діяльності окремих державних органів, підрозділів $i$ служб, службових повноважень державних службовиів задля виявлення потенційних можливостей для зловживання; запровадження сучасних психотехнологій для проведення професійно-психологічного добору кадрів з урахуванням специфіки служби задля запобігання прийняттю на службу в органи влади осіб, які пов'язані з антигромадськими елементами, кримінальними структурами; визначення переліку посад працівників управлінських ланок, кандидати на замішення яких підлягають обов'язковій спеизіальній перевірці; запровадження на постійній основі профілактичної ротації керівного складу через кожні п'ять років; розроблення спеціальних програм навчання та підвищення кваліфікації працівників з питань запобігання корупції у професійній та службовій діяльності; запровадження практики оперативного інформування кадрів щодо усіх виявлених фактів корупції серед їх працівників; оприлюднення через засоби масової інформації та прес-службу матеріалів, що пов'язані з корупиійними діями працівників, запровадження постійної практики радіо- та телевізійних виступів (звітів) перед населенням 
керівників територіальних органів з висвітленням як позитивних, так $і$ негативних фактів їх роботи на місиях; вирішення проблеми про підвищення рівня матеріального забезпечення державних службовиів із низькими окладами і встановлення доплат до їх заробітної плати залежно від кількості та якості роботи, зокрема запровадження грошової та іншої компенсаціі за роботу в позаробочий час.

Ключові слова: спеціальнокримінологічний рівень, запобігання, корупційні злочини, державні службовці, антикорупційна політика.

Dovban I. Special and criminological measures for the prevention of crimes committing by public servants

The article identifies special and criminological measures for the prevention of crimes committing by public servants. At the special and criminological level, it is proposed to supplement the current measures for the prevention of crimes committing by public servants, by such as: 1) imposing on detectives of the National Anti-Corruption Bureau of Ukraine the obligation to initiate operational and investigative cases (to change the right specified in paragraph 1, part 1 of Article 17 of the Law of Ukraine "On the National AntiCorruption Bureau of Ukraine"), thus bringing the status legislation in line to operative and search (part 1 of Article 9 of the Law of Ukraine "On operative and search activity"); 2) specification of the procedure for registration, accounting and consideration of applications and notifications on criminal offenses referred by law to the National AntiCorruption Bureau of Ukraine, or on unfounded assets - by providing special procedures for the National Anti-Corruption Bureau of Ukraine in the Regulations on the Unified Register of Pre-trial Investigations, the procedure for its formation and maintenance; 3) analysis of the activities of individual state bodies, divisions and services, official powers of public servants in order to identify potential opportunities for abuse; 4) introduction of modern psychotechnologies for professional and psychological selection of personnel taking into account the specifics of the service in order to prevent the recruitment of persons associated with anti-social elements, criminal structures; 5) determination of the list of positions of employees of management units, candidates for replacement of which are subject to obligatory special check; 6) introduction on a permanent basis of preventive rotation of management staff every five years; 7) development of special training programs and professional development of employees on the prevention of corruption in professional and official activities; 8) introduction of the practice of prompt informing of personnel on all revealed facts of corruption among their employees; 9) publication through mass media and press service of materials related to corrupt actions of employees, introduction of constant practice of radio and television speeches (reports) to the population of heads of territorial bodies with coverage of both positive and negative facts of their work on places; 10) solving the problem of increasing the level of material security of public servants with low salaries and setting surcharges to their salaries depending on the quantity and quality of work, including the introduction of cash and other compensation for work outside working hours.

Key words: special and criminological level, prevention, corruption crimes, public servants, anti-corruption policy. 


\section{Література}

1. Конституиія України : Закон України від 28 червня 1996 р. № 254к/96-ВР. Відомості Верховної Ради України. 1996. № 30. Cm. 141 .

2. Тютюгін B.I., Гродецький Ю.В., Гізимчук С.В. Злочини у сфері службовоі діяльності та професійної діяльності, пов'язаної з наданням публічних послуг: навчально-практичний посібник / за ред. В.Я. Тація. Харків : Право, 2014. 227 с.

3. Кримінальний кодекс України: Закон України від 5 квітня 2001 р. № 2341-III. Відомості Верховної Ради України. 2001. № 25-26. Cm. 131 .

4. Клюев М.м. Запобігання злочинності: кримінологічні засади програмування. Київ : KIT, 2010. 208 с.

5. Литвак O.M. Злочинність, ї причини та профілактика. Київ : Україна, 1997. 167 c.

6. Джужа О.М., Василевич В.В., КолбО.Г. та ін. Кримінологія : навчальний посібник. Київ : Атіка, 2009. 312 с

7. Голіна B.B. Запобігання злочинності (теорія $і$ практика) : навчальний посібник. Харків : Національна юридична академія України імені Ярослава Мудрого, 2011. 120 с

8. Закалюк А.П. Курс сучасної української кримінології: теорія і практика : у 3 кн. Київ : Iн Юре, 2007. Кн. 1 : Tеоретичні засади та історія української кримінологічної науки. 424 с.

9. Криминология : учебник / под. общ. ред. А.И. Долговой. Москва : ИНФРА-МHOPMA, 1997. 784 c.

10. Джужа О.М., Кондратьев Я.Ю., Кулик О.Г., Михайленко П.П. та ін. Кримінологія : підручник для студентів вищих навчальних закладів. Київ : Юрінком Iнтер, 2002. 416 c.

11. Про Національне антикорупиійне бюро України : Закон України від 14 жовтня 2014 р. № 1698-VII. Відомості Верховної Ради. 2014. № 47. Cm. 2051.

12. Валле B.О. Революиійне антикорупиіине законодавство як фактор суспільних трансформацій в Україні. URL: http: / / www.viravallee.com / books.

13. Чечерський B.I. Окремі проблеми нормативного регулювання статусу Національного бюро розслідувань України. Науковий вісник Ужгородського наиіонального університету. 2015. Bun. 32. T. 3. C. 145-148.

14. Зауваження Головного юридичного управління Anарату Верховної Ради України до проєкту Закону «Про внесення змін до деяких законодавчих актів України щодо забезпечення діяльності Національного антикорупиійного бюро України та Національного агентства з питань запобігання корупuï̈. URL: http: / / w1.c1.rada.gov.ua.

15. Про затвердження Положення про порядок ведення Єдиного реєстру досудових розслідувань : Наказ Генеральної прокуратури України від 6 квітня 2016 р. № 139. URL: https: / / zakon.rada.gov.ua/ laws / show / z0680-16.

16. Про оперативно-розшукову діяльність : Закон України від 18 лютого 1992 р. № 2135-ХII. Відомості Верховної Ради України. 1992. № 22. Ст. 303.

17. Татаров О.Ю., Чернявський С.С. Досвід Грузії щодо реалізаціі нового кримінального процесуального законодавства в діяльності органів внутрішніх справ. Науковий вісник Національної академї внутрішніх справ. 2013. № 2. C. 390-400 